\title{
Legume Crop Residue Management on Productivity of Succeeding Maize - An Overview
}

\author{
S. Padma*, M. Sree Rekha, K. Jayalalitha and P. Prasuna Rani \\ Agricultural College, Bapatla, Andhra Pradesh, India \\ *Corresponding author
}

\section{A B S T R A C T}

\begin{tabular}{|l|}
\hline Key w o r d s \\
Incorporation, \\
Legumes, Maize \\
\hline Article Info \\
\hline Accepted: \\
24 May 2019 \\
Available Online: \\
10 June 2019 \\
\hline
\end{tabular}

\section{Introduction}

Maize is known as queen of cereals and is grown throughout the year mainly due to photo-thermo-sensitive character. Intensive cultivation along with the depletion of natural resources, continuous increase in costs of inputs and food prices along with climatic variability is limiting factor for enhanced food production.

Hence, use of organic manures is now gaining momentum, but incorporation of organic manures requires bulk quantities which may not be much affordable by small and marginal farmers. In this context, crop residues of previous grown legumes can be used to overcome the problem of soil fertility.
Maize is considered as important cereal crop which occupies third position after rice and wheat. Maize is considered as heavy feeder of nutrients and requires continuous and assured supply of nutrients throughout its growth period. Now-a-days, maize is grown under intensive agricultural conditions with more of chemical fertilisers although organic ertilizers are minimally used. The increased change in prices of fertilisers, deterioration of soil health and environmental concerns, are necessitating the use of organic manures which is gaining momentum. In this concern, incorporation of crop residues helps in enhancing soil fertility particularly of legumes. The update for the research undertaken on influence of legume incorporation on growth and productivity of maize is provided in this overview. 
fertilisers should be adopted for achieving potential yields of maize. Earlier researchers stated that grain yield of maize was higher when leguminuous cover crops were incorporated (Tanimu et al., 2007).

Crop residue management of legumes effect on growth and yield of succeeding maize

\section{Growth Parameters of maize}

Onwonga et al., (2014) conducted two experiments at Njoro and Molo on soils of mollic Phaeozems and mollic Andisols, respectively and reported that drymatter yield of maize was higher with Crotalaria rotation, followed by cowpea when compared to natural fallow.

Shuaibu et al., (2015) reported that incorporation of legume residues of soybean and cowpea resulted in increased plant height of maize when compared to fallow at Abubakar Tafaka Balewa University, Bauchi, Nigeria.

The plant height of maize at 8 and $10 \mathrm{WAP}$ produced taller plants in cowpea green manure treated plots than the control as per the research findings carried out at the University of Agriculture, Abeokuta, Nigeria by Fabunmi and Balogun, 2015.

Zero tillage and permanent bed tillage in maize-chickpea-Sesbania crop rotation resulted in higher leaf area index and net assimilation rate when compared to conventional tillage from the findings of Yadav et al., (2017) at ICAR-IIMR, New Delhi. Mehran Ali et al., (2018) conducted an experiment at the University of Agriculture, Peshawar and observed that various nitrogen sources and mungbean residues incorporated with mould board plough resulted in higher biological yield than control in maize.

\section{Yield attributes and yield of maize}

The results with regard to hundred seed weight, harvest index and total seed yield of corn were highest with incorporation of cowpea residues of different varieties and are comparable with fertilizer applied plots as per the field experiment results conducted at Ghana on soils of Ferric Acrisols by Fataah and Addo (2016).

Parihar et al., (2016) from six year study on conservation agriculture trail with retention of 30 per cent crop residues along with 100 per cent retention of Sesbania crop residue in intensive irrigated maize systems found that crop productivity increased in maize-mustardmungbean and maize-wheat-mungbean systems at Indian Institute of Maize Research (ICAR), New Delhi.

Highest cob length and maize yields were recorded with Eupatorium mulching (3.87 t $\mathrm{ha}^{-1}$ ) followed by soybean green manure incorporation insitu + one hand weeding (3.64 $\mathrm{t} \mathrm{ha}^{-1}$ ) under rainfed organic farming system of maize production in sandy clay loam soils of mid hills of Meghalaya (Anup Das et al., 2016).

Biomass of corn and yield parameters like shelling percentage and harvest index were enhanced with application of Cajanus cajan mulch@5 t ha-1which is comparable to the NPK treated plot. The grain yield was highest with NPK during dry season while in wet season Cajanus cajan mulch produced higher corn yields on clay loam alfisol at Nigeria (Awopegba et al., 2016).

Broad bed furrow and flat bed with no tillage along with retention of crop residues on the soil surface combined with inorganic fertilisers and FYM produced maize equivalent yields of 7914 and $7786 \mathrm{~kg} \mathrm{ha}^{-1}$ respectively, when compared to incorporation 
and conventional tillage with enhanced yields for all the cropping systems of groundnutsorghum, soybean-wheat and maize-chickpea from the experimental findings of Prabhamani and Babalad, 2017 at UAS, Dharwad.

Corn yield of $37,290 \mathrm{~kg}$ ha-1 was obtained with soybean residue along with supplemental dose of phosphorus and potassium fertiliser which was found similar to inorganic fertiliser treated plot as per the research findings of Almaz et al., 2017 at Malaysia.

Maize protein yield and maize protein yield for adults recorded maximum with conservation tillage (Zero tillage and permanent bed) under legume based maize rotation when compared to conventional tillage and the highest values was with Maizechickpea-Sesbania cropping system (Yadav et al., 2017).

Kalasa et al., 2018 from the study carried at Kandeu and Manjawira Extension Planning areas, Central Malawi observed that maize grain yields following incorporation of legume crop residues were significantly higher than continuous sole cropped maize. The maize equivalent yields were maximum with maize-wheat-mungbean when compared to maize-lentil-mungbean under conservation tillage with retention of crop residues in the plots on light textured soil of Nepal (Hari Kumar et al., 2018).

Mulching and incorporation of cowpea residues resulted in maximum number of ears and 100 kernel weight with highest grain and stover yield of corn in maize-cowpea intercrops over no crop residue.

Among crop residue management, incorporation performed better for yield parameters and yield of corn than surface mulching of cowpea residues at Mtwapa, Kenya (Ndiso et al., 2018).
Jat et al., 2019 from their long term study recorded 10.1 to $16.7 \%$ of maize crop grain yields with full conservation tillage of residue retention than the plots where residues were removed under maize-mustard-mungbean and maize-wheat-mungbean crop rotations.

\section{Responsiveness of maize to fertilizer application}

Adesoji et al., (2013) from the experiment conducted at Nigeria reported that at a given $\mathrm{N}$ rate, legume green manure produced significantly higher grain yield than weedy fallow. At a given legume green manure, increasing $\mathrm{N}$ rate beyond 60 and $90 \mathrm{~kg} \mathrm{~N} \mathrm{ha}^{-1}$ did not produce significant differences in grain yield. However, green manures Mucuna, lablab and soybean responded to application of $60 \mathrm{~kg} \mathrm{~N} \mathrm{ha}{ }^{-1}$ in increasing yields of maize.

Shuaibu et al., (2015) at Nigeria found that application of $60 \mathrm{~kg} \mathrm{~N}^{-1}$ as a top dress to sorghum grown on cowpea or soybean residue increased the grain yields of sorghum. Sorghum intercropped with soybean left to maturity with nitrogen applied at $40 \mathrm{~kg} \mathrm{~N}^{-1}$ resulted in higher soil $\mathrm{NO}_{3}-\mathrm{N}$ along with increased grain yields at Kenya (Kebeney et al., 2015).

Fataah and Addo, 2016 from the field experiment conducted at Ghana reported that cowpea variety Asetenapa residue incorporated plot showed the greatest yield which was comparable with the yields obtained from the fertilized plots. It suggested that incorporation of cowpea residues does not require application of chemical fertilizer.

Daramy et al., (2017) at KNUST, Ghana reported that all the plots which were expected to contain residual $\mathrm{N}$ and $\mathrm{P}$ from previous season produced similar maize growth and yield with the plots that did not 
receive $\mathrm{N}$ and $\mathrm{P}$ fertilizers from previous season but had incorporated cowpea residues as means of fertilization which implies that recycling of grain legume residues after harvest can produce net nitrogen as high as $140 \mathrm{~kg} \mathrm{~N} \mathrm{ha}^{-1}$ depending upon the legume.

Kalasa et al., (2018) from the experiment conducted at Ntcheu district of Central Malawi concluded that the average maize grain yields following legume cropping systems were comparatively higher than maize grain yields from maize without nitrogen addition from inorganic fertilizers.

It was found that sole groundnut, top dressed with $23 \mathrm{~kg} \mathrm{~N} \mathrm{ha}^{-1}$ was higher $\left(3352 \mathrm{~kg} \mathrm{ha}^{-1}\right)$ compared to maize fertilized with $92 \mathrm{~kg} \mathrm{~N}$ ha ${ }^{1}$ (3159 kg ha ${ }^{-1}$ ) which implies that organic matter addition from legumes with low nitrogen inputs from inorganic fertilizers is a viable option in improving maize grain yield.

\section{Nutrient uptake}

The research findings of Shafi et al., (2010) found that mulch and residue incorporation improved maize stover $\mathrm{N}$ uptake by 2.23 and $6.58 \%$ in maize crop at Peshawar, Pakistan.

Incorporation of cowpea residues and herbaceous legumes to sorghum resulted in significantly higher nitrogen content in sorghum than that of control at 6 WAI (Usman, 2013) on Ultisols at Guinea.

Kouelo et al., (2013) from an experiment conducted on degraded sandy soil at National Institute of Agricultural Research, Benin observed that Mucuna residues incorporation increased grain nitrogen uptake $(149.4 \mathrm{~kg} \mathrm{~N}$ $\mathrm{ha}^{-1}$ ) when compared to no residue incorporated plot.

Total uptake of nutrients (N, P, K) by maize crop was more in crop residue incorporated plots than without residue incorporation plots on sandy loam soil at BAU, Ranchi (Asha Kumari et al., 2018).

\section{Soil microbial biomass and activity}

Awanish Kumar et al., (2017) with four cropping systems along with reduced tillage, no tillage and conventional tillage found enhanced dehydrogenase activity $(122.35 \mu \mathrm{g}$ TPF $\mathrm{g}^{-1}$ day $^{-1}$ ) with no tillage while fluorescein diacetate hydrolysis activity was more with reduced tillage $(30.85 \mu \mathrm{g}$ fluorescein $\mathrm{g}^{-1} \mathrm{~h}^{-1}$ ) in soybean+pigeonpea and maize-gram cropping systems.

Maize-chickpea-Sesbania with permanent bed and zero tillage by retention of $30 \%$ crop residues on soil surface has dehydrogenase activity of 39.6 and $24.5 \%$ in 0-5 and 5-15 $\mathrm{cm}$ depth of soil respectively, which were higher than conventional tillage and lower values were with maize-mustard mungbean (Amresh Chaudhary et al., 2017).

Soil microbial biomass $\mathrm{C}$ and $\mathrm{N}$ recorded higher values $\left(3.86\right.$ and $\left.1.60 \mathrm{mg} \mathrm{kg}^{-1}\right)$ at 10 $\mathrm{cm}$ depth of soil with no-tillage when compared to chisel tillage with four crop rotations among which corn-soybean has slightly higher values (Zuber et al., 2018).

Banda et al., (2018) revealed that in maizecowpea rotation system the soil microbial biomass carbon was higher which ranged from 1.96 to $2.28 \mathrm{mg} / \mathrm{g}$ on Acrisols and Alisols in Chipata District, Zambia.

Maize-wheat-mungbean crop rotation with zero tillage along with crop residue retention resulted in 56\% and $70 \%$ microbial biomass carbon and nitrogen respectively, $73 \%$ and $40 \%$ of phosphatise activity and $\beta$-glucosidase activity respectively and fungal diversity in comparison with rice-wheat system (Madhu Choudhary et al., 2018). 


\section{Economics}

Meena et al., 2015 reported that under conventional tillage system, residue retention of greengram significantly increased the benefit-cost ratio (1.985) with a net profit of $11,543 \mathrm{Rs} \mathrm{ha}^{-1}$ in maize based cropping systems.

Parihar et al., (2016) concluded that zero tillage system of Maize-Mustard-Mungbean gave significantly higher net profits in first and sixth year of study while in the rest of the years, Maize-Wheat-Mungbean system resulted in highest net returns.

Prabhamani and Babalad, 2017 concluded that surface retention of crop residues with no tillage and flat bed method resulted in net profit of Rs 60654 ha $^{-1}$ over incorporated and conventional tillage.

Naab et al., 2017 from the analysis of partial budget by retention of crop residues in zero tillage system of maize-soybean rotation found that cost of production for maize or soybean is $20-29 \%$ cheaper with highest returns and Benefit-cost ratio when compared to conventional tillage.

Hari Kumar et al., 2018 concluded that retention of crop residues under no tillage gave 114\% higher net returns (NRs $40200 \mathrm{ha}$ $\left.{ }^{1}\right)$ under maize based cropping system at Nepal.

From the above reviews, it can be concluded that, incorporation or mulching of crop residues proved to improve the performance of succeeding crops which is reflected in terms of growth and accumulation of drymatter. Significant response was also observed in yield attributes and yield of succeeding crop due to increased fertility status of soil and uptake of nutrients by the crop when compared to residue removal plots.
Soil microbial activity was improved due to placement or incorporation of residues over residue removed treatments. Incorporation or mulching of legume crop residues also resulted in higher net returns and benefit-cost ratio.

\section{References}

Adesoji, A.G., Abubakar, I.U and Labe, D.A. 2013. Contributions of short duration legume fallow to maize (Zea mays L.) varieties under different nitrogen levels in a semi-arid environment. American Journal of Experimental Agriculture. 3 (3): 542-556.

Almaz, M.G., Halim, R.A., Yusoff, M.M and Wahid, S.A. 2017. Effect of incorporation of crop residue and inorganic fertilizer on yield and grain quality of maize. Indian Journal of Agricultural Siences. 51 (6): 574-579.

Amresh Chaudary, Mahesh C. Meena, Chiter M. Parihar and Abir Dey. 2017. Effect of long term conservation on soil organic carbon and dehydrogenase activity under maize based cropping sytems. International Journal of Current Microbiology and Applied Sciences. 6(10): 437-444.

Anup Das, Manoj Kumar, Ramkrushna, G.I., Patel, D.P., Jayanta Layek, Naropongla, Panwar, A.S and Nagchan, S. V. 2016. Weed management in maize under rainfed organic farming system. Indian Journal of Weed Science. 48 (2): 168172.

Awanish Kumar, Anusuiya Panda, Srivastava, L.K and Mishra, V.N. 2017. Effect of conservation tillage on biological activity in soil and crop productivity under rainfed vertisols of central India. International Journal of Chemical Studies. 5 (6): 1939-1946.

Fabunmi, T.O and Balogun, R.O. 2015. Response of maize (Zea mays L.) to 
green manure from varying populations of cowpea in a derived savannah of Nigeria. African Journal of Food, Agriculture, Nutrition and Development. 15 (3): 10138-10152.

Fataah, J and Sarkodie-Addo. J. 2016. Effect of cowpea residue nitrogen on maize growth and yield in the semi-arid deciduous region of Ghana. International Journal of Science and Technology. 6 (9):21-23.

Felix A. Kouelo, Pascal Houngnandan and Dercon Gerd. 2013. Contribution of seven legumes residues incorporated into soil and NP fertilizer to maize yield, nitrogen use efficiency and harvest index in degraded soil in the center of Benin. International Journal of Biological and Chemical Sciences. 7 (6): 2468-2489.

Hari Kumar Prasai, Shrawan Kumar Sah, Anand Kumar Gautam and Anant Prasd Regmi. 2018. Conservation tillage for productivity and profitability of wheat and lentil in maize based cropping system in far western Nepal. Journal of Bangladesh Agricultural University. 16 (3): 403-410.

Jat, S.L., Parihar, C.M., Singh, A.K., Nayak, H.S., Meena, B.R., Kumar, B., Parihar, M.D and Jat, M.L. 2019. Differential response from nitrogen sources with and without residue management under conservation agriculture on crop yields, water-use and economics in maizebased rotations. Field Crops Research. 236: 96-110.

Jesse B. Naab, George Y. Mahama, Iddrisu Yahaya and Prasad, P.V.V. 2017. Conservation agriculture improves soil quality crop yield and incomes of small holder farmers in northwestern Ghana. Frontiers in Plant Science. 8:1-15.

John S.K. Banda, Alice M. Mweetwa, Munsanda Ngulube and Elijah Phiri. 2018. Chemical and biological properties of soils under maize-cowpea cropping systems in conservation agriculture. Journal of Agricultural Sciences. 10 (5):100-108.

Joseph Blackwell Kalasa, Wezi Grace Mhango, George Yobe Kanyama-Phiri and Max Williams Lowole. 2018. Maize response to doubled-up legumes, compost manure and inorganic fertilizer on smallholder farms in Ntcheu district of Malwi. African Journal of Agricultural Research. 13 (21): 11011110.

Madhu Choudhary, Parbodh Chander Sharma, Hanuman Sahay Jat, Andrew McDonald, Mangi Lal Jat, Sharda Choudhary and Neelam Garg. 2018. Soil biological properties and fungal diversity under conservation agriculture in Indo-Gangetic plains of India. Journal of Soil Science and Plant Nutrition. 18 (4): 1142-1156.

Matthew Awopegba, Moses Awodun and Segun Oladele. 2016. Maize (Zea mays) biomass and yield as influenced by leguminuous and non-leguminuous mulch type in southwestern Nigeria. Bulgarian Journal of Soil Science. 1 (2): 154-169.

Meena, J.R., Umakant K. Behera. Debasis Chakraborthy and Sharma, A.R. 2015. Tillage and residue management effect on soil properties, crop performance and energy relations in greengram (Vigna radiata $\mathrm{L}$.) under maize based cropping systems. International Soil and Water Conservation Research. 3:261-272.

Mohammad Shafi, Jehan Bakht, Attaullah and Mohammad Khan. 2010. Effect of crop sequence and crop residues on soil $\mathrm{C}$, soil $\mathrm{N}$ and yield of maize. Pakistan Journal of Botany. 42 (3): 1651-1664.

Moses Ahmed Daramy, Joseph SarkodieAddo and Gibrilla Dumbuya. 2017. Effects of residual fertility and cowpea residues on succeeding maize growth 
and yield of Ghana. International Journal of Sciences: Basic and Applied Research. 33 (3): 227-235.

Ndiso, J.B., Chemining, G.N., Olubayo, F.M and Saha, H.M. 2018. Effect of cowpea crop residue management on soil moisture content, canopy temperature, growth and yield of maize- cowpea intercrops. International Journal of Agriculture, Environment and Bioresearch. 3 (5): 231-250.

Parihar, C.M., Jat, S.L., Singh, A.K., Kumar, B., Yadvinder-Singh, Pardhan, S., Pooniya, V., Dhauja, A., Chaudary, V., Jat, M.L., Jat, R.K and Yadav, O.P. 2016. Conservation agriculture in irrigated intensive maize-based system of north- western India: Effects on crop yields, water productivity and economic profitability. Field Crops Research. 193:104-116.

Prabhamani, P.S and Babalad, H.B. 2017. Effect of conservation tillage systems and nutrient management practices on productivity and economics of crops in different crop sequence under rainfed conditions. International Journal of Pure and Applied Bioscience. 5 (5): 935-943.

Shuaibu, Y.M., Garba, A.A and Voncir, V. 2015. Influence of legume residue and nitrogen fertilizer on the growth and yield of sorghum (Sorghum bicolor L. Monech) in Bauchi state, Nigeria. African Journal of Food, Agriculture, Nutrition and Development. 15 (3):
10060-10076.

Stacy M. Zuber, Gevan D. Behnke, Emerson D. Nafziger and Maria B. Villamil. 2018. Carbon and nitrogen content of soil organic matter and microbial biomass under long term crop rotation and tillage in Illinois, USA. Agriculture. 8 (37):1-12.

Tanimu, J and Iwuafor, E.N.O., Oduze, A.C and Tian, G. 2007.Effect of incorporation of leguminous cover crops on yield and yield components of maize. World Journal of Agricultural Sciences. 3 (2): 243-249.

Usman, A., Osunde, A.O and Bala, A. 2013. Nitrogen contribution of some selected legumes to a sorghum based cropping system in the southern Guinea savanna of Nigeria. African Journal of Agricultural Research. 8 (49): 64466456.

Yadav, M.R., Parihar, C.M., Jat, S.L., Singh, A.K., Rakesh Kumar, Yadav, R.K and Parihar, M.D. 2017. Impact of legume intensified crop rotations and tillage practices on maize productivity vis-a-vis $\mathrm{C}$ and $\mathrm{N}$ dynamics on a sandy loam soil in north-western Indo-Gangetic plains of India. Legume Research. 40 (6): 1028-1037.

Yadvinder-Singh, Bijay-Singh, Timsina and Jagadish. 2005. Crop residue management for nutrient recycling and improving soil productivity in rice based cropping systems in the tropics. Advances in Agronomy. 85: 269-407.

\section{How to cite this article:}

Padma, S., M. Sree Rekha, K. Jayalalitha and Prasuna Rani, P. 2019. Legume Crop Residue Management on Productivity of Succeeding Maize - An Overview. Int.J.Curr.Microbiol.App.Sci. 8(06): 3136-3142. doi: https://doi.org/10.20546/ijcmas.2019.806.374 